\title{
Genetic Variation of Mantled Howler Monkeys (Alouatta palliata) from Costa Rica ${ }^{1}$
}

\author{
Maria E. Zaldivar ${ }^{2}$ \\ Universidad de Costa Rica, Escuela de Biología, Ciudad Universitaria Rodrigo Facio, San Jose, Costa Rica
}

Kenneth E. Glander

Department of Biological Anthropology and Anatomy, Duke University, Durham, North Carolina 27708, U.S.A.

Oscar Rocha, Gabriel Aguilar, Elida Vargas, Gustavo A. Gutierrez-Espeleta

Universidad de Costa Rica, Escuela de Biología, Ciudad Universitaria Rodrigo Facio, San Jose, Costa Rica

and

Ronald Sanchez

Universidad de Costa Rica, Departamento de Biologia, Sede Regional de Occidente, San Ramón, Costa Rica

\begin{abstract}
We examined genetic diversity of howler monkeys (Alouatta palliata) from Costa Rica. Blood samples of howler monkeys were collected at various locations in Costa Rica, and electrophoresis of total plasma proteins yielded no variation. We also conducted starch gel electrophoresis of red cell isozymes and did not find variation for any of the 14 loci analyzed (i.e., ACP, ADA, CA2, EST, GPI, IDH, LDH-1, LDH-2, MDH, PGD, PGM-1, PGM-2, SOD, and TPI). These findings were compared with the levels of genetic variation for A. seniculus and A. belzebul from one Brazilian population. Four of the 14 isozymes (ADA, GPI, PGD, and SOD) showed more than one allele for these species. Both $A$. seniculus and $A$. belzebul from Brazil showed similar levels of genetic variation. The potential causes of the low genetic variation in A. palliata from Costa Rica are discussed.
\end{abstract}

\section{RESUMEN}

Se estudió la diversidad genética de los monos congo (Alouatta palliata) de Costa Rica. Se recolectaron muestras de sangre en varias localidades de Costa Rica. El análisis de las proteínas totales del plasma mediante electroforesis no mostró variación. El análisis de las isoenzimas de glóbulos rojos mediante electroforesis en geles de almidón tampoco mostró variación para ninguno de los 14 loci analizados (i.e., ACP, ADA, CA2, EST, GPI, IDH, LDH-1, LDH-2, MDH, PGD, PGM-1, PGM-2, SOD, y TPI). Estos resultados se compararon con los niveles de variación genética en $A$. seniculus y $A$. belzebul de una población de Brasil. Estas especies presentaron más de un alelo en 4 de las 14 isoenzimas analizadas (ADA, GPI, PGD, y SOD). Tanto A. seniculus como A. belzebul presentaron niveles comparables de variación genética. Se discuten las causas potenciales de la poca variación genética en $A$. palliata de Costa Rica.

Key words: dispersal; habitat fragmentation; howler monkeys; isozymes; New World monkeys.

Central American howlers (Alouatta palliata AND $A$. PIGRA) EXHibit EXTREMely LOW LeVELS OF GENETIC VARIATION for plasma proteins and red cell isozymes (Malmgren \& Brush 1978, Froelich \& Thorington 1982, James et al. 1997). This observation contrasts markedly with the high levels of genetic variation shown by howler species from South America ( $A$. seniculus, $A$. belzebul, and $A$. fusca; Lima et al. 1990, Pope 1992, Sampaio et al. 1996).

${ }^{1}$ Received 28 May 2002; revision accepted 24 August 2003.

2 Corresponding author: Tel. (506) 207-4644, Fax (506) 207-4216, e-mail: marizaldivar@hotmail.com
It has been proposed that the low genetic diversity of Central American howlers is due to the action of random genetic drift (Froelich \& Thorington 1982, Pope 1996, James et al. 1997). Random genetic drift leads to the loss of genetic diversity within populations (Falconer 1989; Futuyma 1989; Ellstrand \& Elam 1993). Under these circumstances, we would expect to find little or no variation within populations. This was the case for the populations described by Malmgren and Brush (1978), Froelich and Thorington (1982), and James et al. (1997), and for those reviewed by Pope (1996). At the same time, random genetic drift promotes genetic differentiation between popula- 


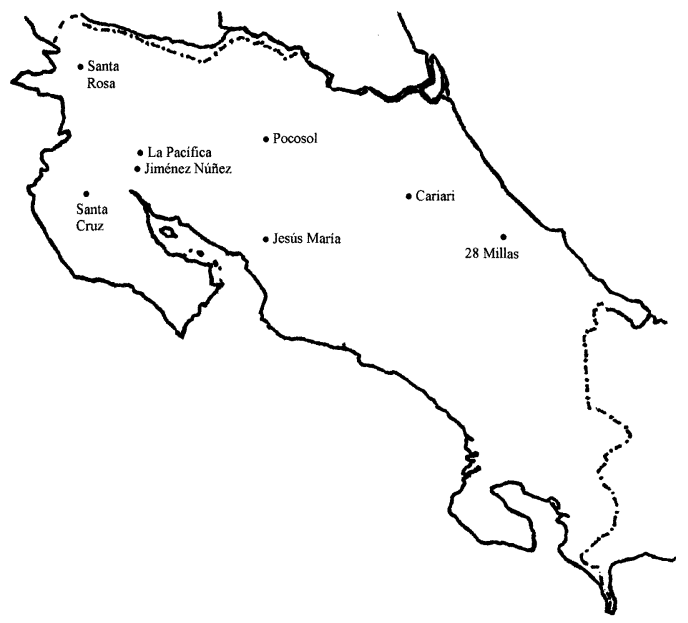

FIGURE 1. Location of study sites in Costa Rica, Central America.

tions since different alleles become fixed in each population (Falconer 1989, Futuyma 1989, Ellstrand \& Elam 1993). Based on this, we would expect to find variation between populations. This issue has not been addressed in previous research studies.

We conducted electrophoretic analyses for plasma proteins and red cell enzymes to characterize genetic variation in mantled howlers (A. palliata) from different sites within Costa Rica. We also did a comparative study between Costa Rican mantled howlers and Brazilian red howlers (A. seniculus) and red-handed howlers (A. belzebul). The possible causes for the low levels of genetic variation in Costa Rican mantled howlers (A. palliata) are discussed.

\section{MATERIALS AND METHODS}

STUdy SPECIES.-Mantled howlers (A. palliata) are one of the most variable of the six howler species, ranging in adult body size from 4.5 to $9.8 \mathrm{~kg}$ for males and 3.1 to $7.6 \mathrm{~kg}$ for females (Ford \& Davies 1992). They are strict herbivores and eat mostly leaves and fruits from a variety of tree species, showing a very flexible diet (Glander 1978, 1981; Chapman 1987, 1990, Crockett \& Eisenberg 1987). Mantled howlers are found from southern Mexico to northern Ecuador (Wolfheim 1983) and live in a wide variety of habitats, including deciduous, riparian, evergreen, and montane forests (Crockett \& Eisenberg 1987). They can occupy altered environments, including small patches of forest neighboring agricultural and urban areas.

Sample collection.-Blood samples were collected from several mantled howler sites in Costa Rica during a period of four years, starting in 1993 (Fig. 1). Table 1 lists the name of the site, the region within which it is located, and the number of samples collected at each site. Most samples came from the Guanacaste region, located on the northwestern side of the country. It has seasonal rains and vegetation typical of lowland deciduous and semi-deciduous dry forests (Holdridge 1967, Janzen 1983). The sample sites were: Santa Rosa National Park, the largest protected area in the region; La Pacifica, a private cattle ranch, tourist resort, and forest reserve (this population has been studied by KEG since 1970); Jimenez Nuñez, an agricultural station with a small forest reserve at the time of the study; and Santa Cruz, a cattle ranch near the town of Santa Cruz.

TABLE 1. Number of samples of Alouatta palliata from each location.

\begin{tabular}{lcc}
\hline \multicolumn{1}{c}{ Species, Site } & \multicolumn{1}{c}{$\begin{array}{c}\text { Geographical } \\
\text { coordinates }\end{array}$} & $\begin{array}{c}\text { Number of } \\
\text { samples }\end{array}$ \\
\hline $\begin{array}{l}\text { A. palliata, Costa Rica } \\
\text { GUANACASTE }\end{array}$ & 137 \\
La Pacifica & & 91 \\
Jimenez Nuñez & $10^{\circ} 46^{\prime} \mathrm{N}, 85^{\circ} 13^{\prime} \mathrm{W}$ & 15 \\
Santa Cruz & $10^{\circ} 25^{\prime} \mathrm{N}, 85^{\circ} 12^{\prime} \mathrm{W}$ & 10 \\
Santa Rosa & $10^{\circ} 25^{\prime} \mathrm{N}, 85^{\circ} 59^{\prime} \mathrm{W}$ & 6 \\
CENTRAL PACIFIC & $10^{\circ} 83^{\prime} \mathrm{N}, 85^{\circ} 61^{\prime} \mathrm{W}$ & 7 \\
Rio Jesus & & \\
ATLANTIC & $10^{\circ} 03^{\prime} \mathrm{N}, 84^{\circ} 52^{\prime} \mathrm{W}$ & 6 \\
28 Millas, Limón & & 1 \\
Cariari, Limón & $10^{\circ} 09^{\prime} \mathrm{N}, 83^{\circ} 38^{\prime} \mathrm{W}$ & 1 \\
Pocosol, San Carlos & $10^{\circ} 37^{\prime} \mathrm{N}, 83^{\circ} 74^{\prime} \mathrm{W}$ & $10^{\circ} 36^{\prime} \mathrm{N}, 84^{\circ} 65^{\prime} \mathrm{W}$ \\
\hline
\end{tabular}


The Atlantic Region, on the eastern side of the country, receives a greater amount of rainfall and the populations studied are from areas with vegetation typical of lowland rain forests (Holdridge 1967, Janzen 1983). Blood samples were collected at three sites: La Suerte, a field station and former cattle ranch; 28 Millas, a banana plantation; and Pocosol, a cattle ranch.

The Central Region included only one site, Rio Jesus. This site is at a higher elevation, with vegetation typical of premontane humid forests (Holdridge 1967, Janzen 1983), and is highly disturbed. The troop sampled occupied a 5 ha fragment of forest neighboring coffee plantations and pasturelands.

All sampled populations were located at least $30 \mathrm{~km}$ from each other, with the exception of Jimenez Nuñez and La Pacifica, which were ca 15 $\mathrm{km}$ from each other. Also, the Atlantic and Pacific Regions are separated by a mountain range running along the center of the country in a north-south direction.

Samples were collected using standard dart gun techniques (Glander et al. 1991). Animals were anesthetized with Telazol (tilethamine hydrochloride and zolazepam hydrochloride) and $5 \mathrm{ml}$ of blood was drawn from their femoral vein using a vacutainer with ICD (isocitrate dextrose) or EDTA as an anticoagulant. Animals were allowed to recover and were then released at the site of capture. The samples were kept cold until processing in the laboratory. Once in the laboratory, the blood samples were centrifuged at low speed for $c a 15$ minutes to separate plasma, white cells, and red cells. The red cells were washed twice with isotonic 9 percent saline solution. Each fraction was stored separately at $-20^{\circ} \mathrm{C}$.

In order to conduct a comparative study between Central and South American howler monkey species, ten samples of red cells from each of two South American species, Brazilian red howlers $(A$. seniculus) and red-handed howlers (A. belzebul), were also included in the analyses. These samples came from the same geographical area in the state of Pará.

Analysis of total plasma proteins.-Plasma proteins of $A$. palliata were analyzed according to their molecular weight using acrylamide gel electrophoresis. A total of 137 samples was analyzed. We followed the procedure described for the Biorad Protean II system, using 7.5 percent acrylamide gels. The electrophoresis was performed at 200 volts for about five hours. Total plasma proteins were stained with Coomasie Blue. We used a mediumweight molecular marker from Promega to identify the size of the proteins analyzed.

Analysis of red cell isozymes.-Red cell isozymes were analyzed using standard starch gel electrophoresis following the methods described by Harris and Hopkinson (1978), Richardson et al. (1986), and Lima et al. (1990). A total of 76 samples of A. palliata was analyzed; only 30 samples from La Pacifica were included in these analyses (Table 1). We also analyzed 10 samples of $A$. belzebul and 10 samples of $A$. seniculus. We examined 14 loci, namely ACP, ADA, CA2, EST, GPI, IDH, LDH1, LDH-2, MDH, PGD, PGM-1, PGM-2, SOD, and TPI. We used 9-11 percent starch gels. All electrophoreses were run overnight at constant voltage (60-75 volts). We followed the staining procedures recommended by Harris and Hopkinson (1978). For multiple loci in the same isozyme system, the most anodal isozyme was arbitrarily numbered "1," with the remaining loci numbered sequentially. The different alleles for each isozyme (locus) were identified in a similar fashion; the most anodal allele was arbitrarily identified as "A," with the remaining alleles identified sequentially.

Genetic analyses were conducted using the program POPGENE 1.31 (Yeh et al. 1999). Using the data from the red cell isozyme electrophoresis, we determined the levels of genetic diversity for each species using common indicators, such as observed number of alleles, effective number of alleles, Nei's diversity index, and the Shannon diversity index. Population differentiation was estimated using Nei's genetic distance between all possible pairs of populations and Wright's F-statistics, determined using the infinite allele model $\mathrm{F}_{\mathrm{st}}$ (Weir \& Cockerham 1984).

\section{RESULTS}

Analysis of total plasma proteins.-The analysis of total plasma proteins discriminated mostly proteins weighing more than $40 \mathrm{kDa}$. The resolution of our gels was not good enough to determine variation in smaller-size proteins. Our data revealed no genetic variation in total plasma proteins of $A$. palliata, as all the individuals examined showed the same banding pattern.

Analysis of RED CELL ISOZYMes.-The analysis of red cell enzymes also showed that $A$. palliata was monomorphic for all loci; i.e., all individuals examined showed the same electrophoretic pattern. 
TABLE 2. Allele frequencies for the red cell enzymes analyzed for each Alouatta species.

\begin{tabular}{|c|c|c|c|c|}
\hline \multirow[b]{2}{*}{ Enzyme } & \multirow[b]{2}{*}{ Allele } & \multicolumn{3}{|c|}{ Species } \\
\hline & & A. palliata & A. seniculus $A$. & belzebul \\
\hline$\overline{A C P}$ & $\mathrm{~A}$ & 1.00 & 1.00 & 1.00 \\
\hline \multirow[t]{2}{*}{$\mathrm{ADA}$} & A & 1.00 & 0.90 & 0.95 \\
\hline & B & 0.00 & 0.10 & 0.05 \\
\hline CA2 & A & 1.00 & 1.00 & 1.00 \\
\hline EST & A & 1.00 & 1.00 & 1.00 \\
\hline \multirow[t]{2}{*}{ GPI } & A & 1.00 & 0.80 & 0.60 \\
\hline & B & 0.00 & 0.20 & 0.40 \\
\hline IDH & A & 1.00 & 1.00 & 1.00 \\
\hline LDH-1 & A & 1.00 & 1.00 & 1.00 \\
\hline LDH-2 & A & 1.00 & 1.00 & 1.00 \\
\hline $\mathrm{MDH}$ & A & 1.00 & 1.00 & 1.00 \\
\hline \multirow[t]{2}{*}{ PGD } & A & 1.00 & 0.55 & 0.30 \\
\hline & B & 0.00 & 0.45 & 0.70 \\
\hline PGM-1 & A & 1.00 & 1.00 & 1.00 \\
\hline PGM-2 & A & 1.00 & 1.00 & 1.00 \\
\hline \multirow[t]{2}{*}{ SOD } & A & 1.00 & 0.65 & 0.90 \\
\hline & B & 0.00 & 0.35 & 0.10 \\
\hline TPI & A & 1.00 & 1.00 & 1.00 \\
\hline
\end{tabular}

Unlike the Costa Rican mantled howler, both South American species, red-handed howlers ( $A$. belzebul) and red howlers (A. seniculus), showed genetic variation for 4 of the 14 loci examined (ADA, GPI, PGD, and SOD). Table 2 shows the frequency of the most common red cell alleles for each species. For all enzymes studied, the alleles observed in mantled howlers (A. palliata) were also observed in the South American species (A. seniculus and $A$. belzebul); however, both South American species exhibited additional alleles not found in A. palliata.

Table 3 shows the value of common indicators of genetic diversity, such as observed number of alleles, effective number of alleles, expected heterozygosity, Nei's diversity index, and the Shannon diversity index. All indicators of diversity show comparable values for $A$. seniculus and $A$. belzebul. As mentioned before, $A$. palliata showed no genetic variation for all of the red cell enzymes that were studied.
TABLE 4. Unbiased Nei's genetic identity (above the diagonal) and genetic distance (below the diagonal) for the three species of Alouatta in this study.

\begin{tabular}{lccc}
\hline \multicolumn{1}{c}{ Species } & A. palliata & A. seniculus & A. belzebul \\
\hline A. palliata & ***** & 0.9746 & 0.9526 \\
A. seniculus & 0.0257 & $* * * * *$ & 0.9895 \\
A. belzebul & 0.0425 & 0.0106 & $* * * *$ \\
\hline
\end{tabular}

The estimated $\mathrm{F}_{\text {st }}$ value for the three species was 0.2478 (Weir \& Cockerham 1984), indicating high levels of genetic differentiation among the three species. Genetic distance between both South American species was smaller than the distances between each of these species and $A$. palliata from Costa Rica. Table 4 shows Nei's unbiased estimates of genetic identity and genetic distance among these species.

\section{DISCUSSION}

The results presented here revealed no genetic variation in total plasma proteins and red cell isozymes among individuals or among sites for Costa Rican howler monkeys ( $A$. palliata). All individuals examined showed the same banding patterns for total plasma proteins and all 14 loci of red cell isozymes analyzed.

Other studies have also found low levels of genetic variation for Central American howler monkeys. For example, Malmgren and Brush (1978) studied the levels of genetic variation among 132 individuals from the population of La Pacifica, Costa Rica, using two-dimensional electrophoresis. They found variation for 2 out of 15 loci, including MDH. Froelich and Thorington (1982) studied 80 individuals from the population on Barro Colorado Island, Panama. They reported variation for two serum proteins and one red cell enzyme, ADA. James et al. (1997) studied 41 black howlers (A. pigra) from Belize and found variation for 2 out of 36 loci, including GPI. Overall, our results

TABLE 3. Indicators of genetic diversity for each Alouatta species.

\begin{tabular}{lccc}
\hline \multicolumn{1}{c}{ Indicator } & A. palliata & A. seniculus & A. belzebul \\
\hline Mean observed no. alleles & $1.00 \pm 0.00$ & $1.29 \pm 0.47$ & $1.29 \pm 0.47$ \\
Mean expected no. alleles & $1.00 \pm 0.00$ & $1.18 \pm 0.34$ & $1.14 \pm 0.30$ \\
Expected heterozygosity & $0.00 \pm 0.00$ & $0.11 \pm 0.19$ & $0.09 \pm 0.17$ \\
Nei's gene diversity & $0.00 \pm 0.00$ & $0.10 \pm 0.18$ & $0.08 \pm 0.16$ \\
Shannon diversity index & $0.00 \pm 0.00$ & $0.15 \pm 0.27$ & $0.13 \pm 0.24$ \\
\hline
\end{tabular}


agree with findings for other Central American populations of howlers, although we found lower levels of genetic variation than those previously reported; all $A$. palliata individuals examined by us were monomorphic for total plasma proteins. In addition, all red cell isozymes were monomorphic, including $\mathrm{MDH}, \mathrm{ADA}$, and GPI, which were found to be variable in the studies previously cited.

More recent studies using eight microsatellite loci and including samples from Panama, Costa Rica, and Mexico, found that A. palliata, on average, has little genetic variation, and there is a northern decline in genetic diversity (Ellsworth \& Hoelzer 1998, Ellsworth 2000). The population from Panama, in the southern range of the species distribution, showed the greatest genetic variation and the population from Mexico, in the northern range, showed the least.

Previous genetic studies of South American howler species led us to expect high levels of genetic variation. Lima et al. (1990) and Sampaio et al. (1996) found that A. seniculus and A. belzebul from various populations within Brazil showed variation for the same loci found to be variable by us. In addition, A. belzebul was polymorphic for EST, $\mathrm{CA} 2, \mathrm{IDH}$, and $\mathrm{LDH}$, and $A$. seniculus was polymorphic for EST, CA2, and MDH (Lima et al. 1990, Sampaio et al. 1996). Pope (1992) also found that $A$. seniculus from Venezuela was polymorphic for PGD, ADA, GPI, and two serum proteins (i.e., Tf and an unidentified protein). Contrary to our results, she found that $A$. seniculus from Venezuela was monomorphic for SOD. Overall, the levels of isozyme variation that we found for $A$. seniculus and $A$. belzebul from Brazil concur with the results reported for these same groups, although we found fewer polymorphic loci (ADA, GPI, PGD, and SOD), but we also had smaller sample sizes.

The lack of genetic variation in Costa Rican howlers contrasts greatly with the high diversity of their South American sister species. Our comparative approach enables us to state that Costa Rican howlers show significantly less isozyme variation than howlers from one of the populations studied by Sampaio et al. (1996) in Brazil. We should point out that the alleles present in Costa Rican howlers were also shared by their Brazilian sister species, but the latter had additional alleles not found in howler monkeys from Costa Rica. These findings match the results obtained by Ellsworth (2000) in a comparative study using microsatellite markers. Ellsworth (2000) found that Central American howlers exhibited lower genetic diversity than a small sam- ple of $A$. seniculus from the site studied by Pope (1992) in Venezuela.

The lack of genetic variation in mantled howlers from Costa Rica also contrasts with the genetic diversity of other cebids from the same region. With the exception of mantled howlers (A. pallia$t a)$, cebids from Costa Rica show a degree of genetic diversity comparable to that of their South American sister species. Elsewhere, we have recorded genetic diversity estimates for squirrel monkeys (Saimiri oerstedi $)$, spider monkeys (Ateles geoffroyi), and capuchins (Cebus capuchinus; Zaldivar et al., pers. obs.).

Our findings fail to support the hypothesis that the low genetic diversity is due to multiple population crashes resulting from the yellow fever epidemics or other catastrophic events within Costa Rica. First, we did not find variation between populations, as we would have expected based on this hypothesis. Perhaps comparisons on a broader geographical scale or larger sample sizes would be necessary to test this hypothesis. Nevertheless, using the same technique, we were able to detect genetic variation in smaller samples of Alouatta species from South America and in squirrel monkeys $(S$. oerstedii) and spider monkeys (A. geoffroyi) from Costa Rica (Zaldivar et al., pers. obs.). Second, howlers are no more vulnerable to yellow fever than other Costa Rican primate species; major yellow fever epidemics would be expected to affect other primate species from the region as much as howlers (D. Leandro, Zoologico Nacional Simón Bolívar veterinarian, pers. comm.). Moreover, these epidemics also occurred in South America. Hurricanes and natural catastrophes, also proposed as another cause resulting in population crashes, are also equally likely to affect all four nonhuman primate species from Costa Rica.

We suggest that the low levels of genetic variation in Central American howlers result from a founder effect during colonization of the Central American isthmus, followed by a rapid population expansion within Central America. A rapidly expanding small founder population of howlers would retain low levels of genetic variation. Later migrants, outnumbered by the descendants of the initial founders, would not contribute much to the genetic pool of this species. A model similar to this was proposed by Hewitt (1996) to explain the genetic effects of Pleistocene ice ages in Europe and North America using the meadow grasshopper (Chorthippus parallelus) as a paradigm. The life history traits of mantled howlers, particularly their high fecundity and their flexible diet and social system, enable them 
to rapidly colonize a wide variety of habitats and experience high rates of population growth. Recent research by Fedigan et al. (1998), Fedigan and Jack (2001), and Clarke et al. (2002), have shown that howlers are capable of very rapid rates of population growth following habitat disturbance or habitat regeneration. This explanation is consistent with that proposed by Ellsworth (2000), who concluded that her genetic data support the colonization of Central America by howlers from northern South America via a series of founder effects.

Summarizing, the paucity of genetic variation among Central American howlers differs not only from the extremely high genetic diversity exhibited by South American howlers, but also from the genetic diversity observed among other Costa Rican primates. We would like to paraphrase Froelich and Thorington (1982) and Pope (1996) by stating that the cause for this should be the howler monkeys' unique evolutionary history within the Central American isthmus.

\section{ACKNOWLEDGMENTS}

The authors thank J. Azofeifa, M. Artavia, A. Araya, and two anonymous reviewers for providing useful comments in a previous version of this manuscript; L. Castro and A. Sequeira for assistance in the lab and I. Salas and many students volunteers for assistance in the field; students from the M.I.R.T. program at Duke University, North Carolina State University, and University of North Carolina, for assistance with both laboratory and fieldwork, and M. I. Sampaio, H. Schneider, and M. P. Schneider for providing blood samples from $A$. seniculus and $A$. belzebul. Special thanks to the owner and manager of Hacienda La Pacifica for allowing us to work on the ranch. This work was funded in part by NSF grants DBC9118876 and SBR-9601766 to M. Teaford and KEG, the Universidad de Costa Rica Dean of Research Grant 11193-316 to MEZ, and Third World Academy of Sciences Grant 95-364 RG/BIO/LA to M. E. Z. This research benefited greatly from a visit to Duke University by MEZ funded by the M.I.R.T. Program at this institution. The authors also thank the Office of International Affairs of the Universidad de Costa Rica for a fellowship to MEZ and OJR, which was instrumental in preparing this manuscript.

\section{LITERATURE CITED}

Chapman, C. 1987. Flexibility in diets of three species of Costa Rican primates. Folia Primatol. 49: 90-105.

- 1990. Ecological constraints of group size in three species of Neotropical primates. Folia Primatol. 55: 1-9.

Clarke, M. R., D. A. Collins, and E. L. Zucker. 2002. Responses to deforestation in a group of mantled howlers (Alouatta palliata) in Costa Rica. Int. J. Primatol. 23: 365-381.

- C. M. Crockett, E. L. Zucker, and M. Zaldivar. 2002. Mantled howler population of Hacienda La Pacifica, Costa Rica, between 1991 and 1998: Effects of deforestation. Am. J. Primatol. 56: 155-163.

Crockett, C. M., and J. F. Eisenberg. 1987. Howlers: Variation in group size and demography. In B. B. Smuts, D. L. Cheney, R. M. Seyfarth, R. W. Wrangham, and T. T. Struhsaker (Eds.). Primate societies, pp. 54-68. University of Chicago Press, Chicago, Illinois.

Ellstrand, N. C., and D. R. Elam. 1993. Population genetic consequences of small population size: Implications for plant conservation. Ann. Rev. Ecol. Syst. 24: 217-242.

Ellsworth, J. A. 2000. Molecular evolution, social structure, and phylogeography of the mantled howler monkey (Alouatta palliata). Ph. D. Dissertation. University of Nevada, Reno, Nevada.

, AND G. A. Hoelzer. 1998. Characterization of microsatellite loci in a New World primate, the mantled howler monkey (Alouatta palliata). Mol. Ecol. 7: 657-666.

Falconer, D. S. 1989. Introduction to quantitative genetics. Longman Scientific and Technical, London, England.

FEDigan, L. M., AND K. JACK. 2001. Neotropical primates in a regenerating Costa Rican dry forest: A comparison of howler and capuchin population patterns. Int. J. Primatol. 22: 689-713.

- L. M Rose, and R. A. Morera. 1998. Growth of mantled howler groups in a regenerating Costa Rican dry forest. Int. J. Primatol. 19: 405-432.

Ford, S. M., And L. C. Davies. 1992. Systematics and body size: Implications for feeding adaptation in New World monkeys. Am. J. Phys. Anthropol. 88: 415-468.

Froelich, J. W., and R. W. Thorington. 1982. The genetic structure and socioecology of howler monkeys (Alouatta palliata) on Barro Colorado Island. In E. G. Leigh Jr., A. S. Rand, and D. M. Windsor (Eds.). The ecology of a tropical forest: Seasonal rhythms and long-term changes, pp. 291-305. Smithsonian Institution Press, Washington, DC.

Futuyma, D. J. 1989. Evolutionary Biology. Sinauer Associates, Sunderland, Massachusetts.

Glander, K. E. 1978. Howling monkey feeding behavior and plant secondary compounds: A study of strategies. In G. G. Montgomery (Ed.). The ecology of arboreal folivores, pp. 561-574. Smithsonian Institution Press, Washington, DC.

1981. Feeding patterns in mantled howler monkeys. In A. C. Kamil and T. D. Sargent (Eds.). Foraging behavior: Ecological, ethological, and psychological approaches, pp. 231-257. Garland Press, New York, New York.

, L. M. Fedigan, L. Fedigan, and C. A. Chapman. 1991. Field methods for capture and measurement of three monkey species in Costa Rica. Folia Primatol. 57: 70-82. 
Harris, H., and D. A. Hopkinson. 1978. Handbook of enzyme electrophoresis in human genetics. North Holland Publishing Co., Oxford, England.

Hewitt, G. M. 1996. Some genetic consequences of ice ages, and their role in divergence and speciation. Biol. J. Linn. Soc. 58: 247-276.

Holdridge, L. R. 1967. Life zone ecology. Tropical Science Center, San Jose, Costa Rica.

James, R. A., P. L. Leberg, J. M. Quattro, and R. Vrijenhoek. 1997. Genetic diversity in black howler monkeys (Alouatta pigra) from Belize. Am. J. Phys. Anthropol. 102: 329-336.

Janzen, D. H. 1983. Costa Rican natural history. University of Chicago Press, Chicago, Illinois.

Lima, M. M. C., M. I. C. Sampaio, M. P. C. Schneider, W. Scheffrahn, H. Schneider, and F. M. Salzano. 1990. Chromosome and protein variation in red howler monkeys. Rev. Bras. Genet. 13: 789-802.

Malmgren, L. A., And A. H. Brush. 1978. Isozymes and plasma proteins in eight troops of golden mantled howler monkeys (Alouatta palliata). In D. J. Chivers and R. A. Joysey (Eds.). Recent advances in primatology III. Evolution, pp. 283-285. Academic Press, London, England.

Pope, T. R. 1992. The influence of dispersal patterns and mating system on genetic differentiation within and between populations of the red howler monkey (Alouatta seniculus). Evolution 46: 1112-1128.

. 1996. Socioecology, population fragmentation, and patterns of genetic loss in endangered primates. In J. C. Avise and J. L. Hamrick (Eds.). Conservation Genetics. Case histories from nature, pp. 119-159. Chapman and Hall, New York, New York.

Richardson, B. J., P. R. Baverstock, and M. Adams. 1986. Allozyme electrophoresis. A handbook for animal systematics and population studies. Academic Press, San Diego, California.

Sampaio, M. I., M. P. C. Schneider, and H. Schneider. 1996. Taxonomy of the Alouatta seniculus group: Biochemical and chromosome data. Primates 37: 65-73.

Weir, B. S., and C. C. Cockerham. 1984. Estimating F-statistics for the analysis of population structure. Evolution 38: $1358-1370$.

Wolfheim, J. H. 1983. Primates of the world: Distribution, abundance, and conservation. University of Washington Press, Seattle, Washington.

Yeh, F. C., R. Yang, and T. Boyle. 1999. Popgene version 1.31: Microsoft window-based freeware for population genetic analysis. University of Alberta, Edmonton, Canada 